\title{
Analisis Struktur APBD Dalam Meningkatkan Pengelolaan Keuangan Daerah Pada Pemerintah Daerah Sumatera Utara
}

\author{
Elizar Sinambela $^{1^{*}}$, Fitriani Saragih ${ }^{2}$, Eka Nurmala Sari ${ }^{3}$ \\ Fakultas Ekonomi dan Bisnis Universitas Muhammadiyah Sumatera Utara \\ Jl. Kapten Muchtar Basri No. 3 Medan 20221 \\ *e-mail : elizarsinambelaumsu@gmail.com
}

\begin{abstract}
ABSTRAK
Tujuan penelitian ini adalah untuk menganalisis Struktur APBD dalam meningkatkan Pengelolaan Keuangan Daerah pada Pemerintah Daerah Sumatera Utara. Tujuan ini dilatarbelakangi oleh kondisi saat ini dimana kinerja pemerintahan masih kurang baik mulai dari daerah sampai ke pusat. Ini dapat diketahui dari efektifitas dan efisiensi kebijakan pengeluaran pemerintah yang belum dapat sesuai dengan target yang ditentukan. Selain itu juga masih banyaknya oknum pemerintah yang melakukan korupsi, atas dana pemerintah. Hakikatnya APBD adalah penjabaran kuantitatif dari tujuan, sasaran pemerintah daerah dan tugas pokok serta fungsi unit kerja, sehingga harus disusun dalam struktur yang berorientasi pada pencapaian tingkat kinerja tertentu. Oleh sebab itu alokasi dana yang digunakan untuk membiayai berbagai program dan kegiatan dapat memberikan manfaat yang benar-benar dirasakan masyarakat dan pelayanan yang berorientasi pada kepentingan publik (PP No 58 Tahun 2005). Berdasarkan kondisi tersebut maka penelitian ini mencoba untuk menganalisis struktur APBD dalam meningkatkan Pengelolaan Keuangan Daerah dengan mengambil kasus pada pemerintahan daerah Sumatera Utara. Dengan menggunakan metode research and development $(R \& D)$.Penelitian ini menemukan bahwa Pengelolaan Keuangan Daerah Propinsi Sumatera Utara belum efektif dan efisien terlihat dari APBD yang menunjukan realisasi pendapatan dan belanja belum dapat mencapai target. Pada Struktur APBD saat ini masih belum sesuai dengan Permendagri nomor 13 Tahun 2006 pada bagian pembiayaan daerah yang ternyata belum jelas diungkap pada struktur APBD. Perencanaan yang baik akan berdampak pada pelaksanaan dan pengawasan keuangan yang baik pula. Sehingga dapat meningkatkan kinerja pemerintah daerah.
\end{abstract}

Kata kunci : Struktur APBD, Pengelolaan Keuangan Daerah. 
The purpose of this study was to analyze the Regional Budget Structure in improving Regional Financial Management in the Regional Government of North Sumatra. This goal is motivated by the current conditions in which government performance is still not good starting from the region to the center. This can be seen from the effectiveness and efficiency of government expenditure policies that have not been able to meet the specified targets. In addition, there are still many government officials who commit corruption, over government funds. The nature of the APBD is the quantitative elaboration of the objectives, targets of the regional government and the main tasks and functions of the work units, so that they must be structured in a structure that is oriented towards achieving certain levels of performance. Therefore the allocation of funds used to finance various programs and activities can provide benefits that are truly felt by the community and services that are oriented to the public interest (PP No. 58 of 2005). Based on these conditions, this study tries to analyze the structure of the APBD in improving Regional Financial Management by taking cases in the regional government of North Sumatra. By using the research and development $(R \& D)$ method. This study found that the Regional Financial Management of North Sumatra Province has not been effective and efficient seen from the Regional Budget that shows the realization of income and expenditure has not been able to reach the target. The current APBD structure is still not in accordance with Permendagri number 13 of 2006 in the regional financing section which apparently has not been clearly revealed in the APBD structure. Good planning will have an impact on the implementation and good financial supervision. So that it can improve the performance of local governments.

Keywords: Regional Budget Structure, Regional Financial Management. 


\section{PENDAHULUAN}

Dalam rangka pertanggungjawaban publik, pemerintah daerah harus melakukan optimalisasi anggaran yang dilakukan secara ekonomi, efisiensi, efektivitas untuk kegiatan masyarakat. Oleh sebab itu, Anggaran Pendapatan dan Belanja Daerah (APBD) yang pada hakikatnya merupakan penjabaran kuantitatif dari tujuan dan sasaran pemerintah daerah serta tugas pokok dan fungsi unit kerja harus disusun dalam struktur yang berorientasi pada pencapaian tingkat kinerja tertentu. Artinya, APBD mampu memberikan gambaran yang jelas tentang tuntutan besarnya pembiayaan atas berbagai sasaran yang hendak dicapai, tugas-tugas dan fungsi pokok sesuai dengan kondisi, potensi, aspirasi dan kebutuhan rill di masyarakat untuk satu periode waktu tertentu. Dengan demikian alokasi dana yang digunakan untuk membiayai berbagai program dan kegiatan dapat memberikan manfaat yang benar-benar dirasakan masyarakat dan pelayanan yang berorientasi pada kepentingan publik (PP No 58 Tahun 2005).

Realisasi Anggaran Pendapatan dan Belanja Daerah (RAPBD) yang dapat dilihat dari Laporan Realisasi Anggaran (LRA). Laporan ini menjadi salah satu Laporan pertanggungjawaban pemerintah daerah yang utama karena anggaran pemerintahan adalah tulang punggung dari penyelenggaraan pemerintahan. Anggaran ini mempunyai peran penting dalam stabilitas, distribusi, alokasi sumber daya publik, perencanaan dan pengendalian organisasi serta penilaian kinerja. Namun dalam kenyataannya selalu saja kita lihat bahwa pertama Realisasi Pendapatan dalam beberapa tahun (studi kasus pada pemerintah daerah Sumatera Utara) belum dapat mencapai target (anggaran). Kedua Anggaran Belanja mengalami peningkatan setiap tahunnya yang tidak sebanding dengan realisasi. Kondisi ini membuat kita mempertanyakan bagaimana sebenarnya kinerja anggaran pendapatan dan belanja daerah (APBD) pada Pemerintah Provinsi Sumatera Utara.

Selain itu saat ini kita ketahui banyaknya para pemimpin daerah yang harus berurusan dengan KPK untuk mempertanggungjawabkan asset publik dan keuangan daerah saat kepemimpinannya maupun setelah habis kepemimpinannya. Karena ketidak jelasan laporan keuangan maupun pengelolaan asset publik yang dilakukan saat kepemimpinannya.

Pengukuran kinerja sektor publik dilakukan untuk memenuhi tiga maksud, pertama untuk memperbaiki kinerja pemerintah, ukuran kinerja dimasudkan untuk membantu pemerintah berfokus pada tujuan dan sasaran program unit kerja, sehingga pada akhirnya akan meningkatkan efektivitas dalam memberikan pelayanan publik. Kedua untuk mengalokasikan sumber daya dan pembuatan keputusan. Ketiga untuk mewujudkan pertanggungjawaban publik dan memperbaiki komumikasi kelembagaan (Mardiasmo, 2004: 121).

Pemerintah Daerah perlu mempersiapkan instrumen yang tepat untuk melakukan pengelolaan aset daerah secara profesional, transparan, akuntabel, efesien dan efektif dari mulai tahap perencanaan, pendistribusian dan pemanfaatan serta pengawasannya. Penelitian ini dirasakan sangat penting mengingat perlu adanya suata instrumen yang tepat untuk merngelola keuangan daerah selain itu kondisi kinerja pemerintah daerah saat ini yang belum maksimal baik di Indonesia pada umumnya dan pemerintah daerah di Sumatera Utara pada khususnya. 


\section{KAJIAN PUSTAKA \\ Pengelolaan Keuangan Daerah}

Peraturan Pemerintah No. 105 tahun 2000, menyatakan bahwa keuangan daerah adalah semua hak dan kewajiban daerah dalam rangka penyelenggaraan pemerintah daerah yang dapat dinilai dengan uang temasuk didalamnya segala bentuk kekayaan lain yang berhubungan dengan hak dan kewajiban daerah tersebut dalam kerangka APBD. Pada permendagri Nomor 13 Tahun 2006, "APBD merupakan pengelolaan keuangan daerah dalam masa 1 (satu) tahun anggaran terhitung 1 Januari sampai 31 Desember". Menurut permendagri nomor 13 Tahun 2006, struktur APBD terdiri dari 3 bagian yaitu pendapatan daerah, belanja daerah dan pembiayaan daerah yang masing-masing didefenisikan sebagai berikut :

a. Pendapatan Daerah yaitu Penerimaan daerah dalam bentuk peningkatan aktiva/penurunan utang dari berbagai sumber dalam periode tahun anggaran yang bersangkutan. Oleh karena itu, pendapatan dapat berupa arus kas aktiva masuk, peningkatan aktiva/pengurangan utang yang bukan berasal dari kontribusi ekuitas pemerintah daerah.

b. Belanja Daerah yaitu Menurut IASC Framework, penurunan dalam manfaat ekonomi selama periode akuntansi dalam bentuk arus keluar/deplesi asset/terjadinya utang yang mengalokasikan berkurangnya ekuitas dana. Menurut Halim (2002 : 54) definisi atau pengertian Belanja daerah adalah pengeluaran pemerintah daerah pada suatu periode anggaran.

c. Pembiayaan Daerah yaitu Pembiayaan daerah adalah sumber-sumber penerimaan dan pengeluaran daerah yang dimasudkan untuk menutupi deficit anggaran/sebagai alokasi surplus anggaran adanya pos pembiayaan merupakan upaya APBD makin inovatif.

Pendapatan dalam APBD meliputi semua penerimaan uang melalui rekening kas umum daerah, yang menambah ekuitas dana, merupakan hak daerah dalam satu tahun anggaran dan tidak perlu dibayar kembali oleh daerah (Halim, 2004). Pendapatan dalam APBD dikelompokkan sebagai berikut: 1) Pendapatan Asli Daerah, 2) Dana Perimbangan, 3) Lain-lain Pendapatan Daerah Yang Sah. Sedangkan Belanja daerah merupakan semua kewajiban daerah yang diakui sebagai pengurang nilai kekayaan bersih dalam periode tahun anggaran yang bersangkutan. Berdasarkan Kepmendagri Nomor 29 Tahun 2002 Belanja terdiri dari:1) Belanja Administrasi Umum, 2) Belanja Operasi dan Pemeliharaan Saran dan Prasarana Publik, 3) Belanja Modal dan 4) Belanja Transfer.

Peraturan Menteri Dalam Negeri ini dapat diketahui bahwa pengelolaan keuangan daerah sudah diberi batasan-batasan yang harus dilakukan, siapa yang harus melakukan dan ditujukan kepada siapa sehingga diharapkan dengan memahami aturan ini para pelaksana pengawasan keuangan daerah terutama tidak keluar dari aturan yang sudah ditetapkan. Peraturan Pemerintah No.105 Tahun 2000 tentang Pengelolaan dan Pertanggungjawaban Keuangan Daerah Pasal 4 menyatakan bahwa "pengelolaan keuangan daerah dilakukan secara tertib taat pada peraturan perundang-undangan yang berlaku, efisien, efektif, transparan dan bertanggung jawab dengan memperhatikan asas keadilan dan kepatuhan." Artinya dalam pengelolaan keuangan daerah harus dilakukan berdasarkan perundang-undangan yang berlaku, efisien, efektif dan transparan serta dapat dipertanggungjawabkan, bukan berdasarkan pada "pesanan proyek tertentu" dalam merencanakan anggaran. 


\section{METODE}

Penelitian ini merupakan penelitian pengembangan atas struktur APBD dalam meningkatkan pengelolaan keuangan daerah yang sudah diterapkan pada pemerintah daerah sumatera utara. Untuk itu penelitian ini akan menggunakan metode research and development $(R \& D)$. Sesuai model pendekatan research and development maka penelitian ini akan menggunakan tahapan-tahapan sebagai berikut : melakukan analisis dengan cara mengumpulkan informasi tentang penerapan pengelolaan keuangan daerah yang dijalankan pemerintah daerah di Sumatera Utara yang menjadi objek penelitian. Pengumpulan data dilakukan dengan cara pengamatan partisipasi dan studi dokumentasi yang digunakan untuk mentabulasi data yang menunjukkan adanya hubungan dengan masalah pengelolaan keuangan daerah. Teknik analisis data yang digunakan adalah deskriptif dan alat statistik yang digunakan adalah statistik deskriptif.

\section{HASIL DAN PEMBAHASAN}

Penelitian ini diawali dengan menganalisis Anggaran dan Realisasi Pendapatan Pada Pemerintah Provinsi Sumatera Utara pada empat tahun terakhir. Dari data yang ada dapat diketahui bahwa setelah dilakukan analisis varians (selisih) data kinerja anggaran pendapatan dari beberapa tahun bisa dikatakan baik. Walaupun belum dapat mencapai target anggarannya. Ini disebabkan oleh pendapatan dari restribusi daerah dan lain-lain PAD yang sah yang hanya mencapai 60\%. Adapun sisi komponen dari pada Pendapatan daerah itu sendiri adalah Pendapatan Asli Daerah, Pendapatan Transfer dan Lain-lain Pendapatan yang Sah.

Adakalanya PAD mencapai diatas $100 \%$. Hal ini biasanya disebabkan oleh beberapa sumber pedapatan mengalami peningkatan atau melebihi target seperti pendapatan pajak daerah, pendapatan restribusi daerah, Pendapatan Transfer, dana bagi hasil sumber daya alam. Pertumbuhan Pendapatan dan PAD Pemerintah Provinsi Sumatera Utara juga dapat dikatakan cukup baik. Pertumbuhan PAD yang meningkat ini disebabkan oleh meningkatnya pendapatan asli daerah, pendapatan transfer.

Untuk melihat sejauhmana pengelolaan keuangan yang dilakukan pemerintah daerah Sumatera Utara selama ini peneliti melakukan analisis dengan berdasarkan Peraturan Menteri Dalam Negeri Nomor 13 Tahun 2006 tentang Pedoman Pengelolaan Keuangan Daerah yang menjabarkan Asas Umum Pengelolaan Keuangan sebagai berikut: 1) Taat pada peraturan perundang-undangan, 2) Efektif, 3) Efisien, 4) Ekonomis, 5) Transparan, 6) Bertanggung jawab, 7) Keadilan , 8) Kepatutan dan 9) Manfaat untuk masyarakat.

Taat pada peraturan perundang-undangan maksudnya adalah pengelolaan keuangan daerah harus berpedoman pada peraturan perundang-undangan. Dalam hal ini pemerintah daerah Sumatera Utara sudah melakukan pengelolaan keuangan daerah atas dasar undang undang. Seperti Undang-Undang Republik Indonesia Nomor 33 Tahun 2004 tentang Perimbangan Keuangan antara Pusat dan Daerah dan Peraturan Menteri Dalam Negeri Nomor 13 Tahun 2006 tentang Pedoman Pengelolaan Keuangan Daerah. 
Efektif merupakan pencapaian hasil program dengan target yang telah ditetapkan, yaitu dengan cara membandingkan keluaran dengan hasil. Untuk melihat Efektif tidaknya pengelolaan keuangan daerah tersebut dapat melalui perbandingan anggaran dengan hasil. Dari laporan anggaran dan realisasi yang ada dapat dilihat bahwa apa yang dianggarkan belum dapat direalisasikan. Hal ini dapat terlihat dari Realisasi pendapatan belum dapat mencapai anggaran yang ditetapkan setiap tahunnya. Dengan menggunakan Rasio Kemandirian Keuangan Daerah bahwa kemandirian Keuangan daerah pada Pemerintah Provinsi Sumatera Utara masuk dalam kemampuan sedang dan mempunyai kecendrungan menurun. Rata-rata rasio kemandirian keuangan yaitu dibawah 100\%. Dari sisi Rasio Efektivitas dan Efisiensi Pajak Daerah bahwa efektivitas pajak daerah pada Pemerintah Provinsi Sumatera Utara cukup efektif dalam merealisasikan pajak daerahnya yang direncanakan dengan rata-rata rasio efektivitas pajak daerah juga masih dibawah $100 \%$. Hal ini disebabkan oleh kesadaran masyarakatan dalam membayar pajak kendaraan bermotor, bea balik nama kendaraan bermotor, pajak air permukaan (APU) dan pajak bahan bakar bermotor.

Dari sisi efisien pengelolaan keuangan daerah Sumatera Utara juga belum efisien. Efisien merupakan pencapaian keluaran yang maksimum dengan masukan tertentu atau penggunaan masukan terendah untuk mencapai keluaran tertentu. Hal ini dapat terlihat dari Rasio efisiensi belanja ini digunakan untuk mengukur tingkat penghematan anggaran yang dilakukan pemerintah. Angka yang dihasilkan dari rasio efisiensi ini tidak bersifat absolut, tetapi relatif. Artinya, tidak ada standar baku yang dianggap baik untuk rasio ini. Kita hanya dapat mengatakan bahwa tahun ini belanja pemerintah daerah lebih efisien dibanding tahun sebelumnya. Pemerintah daerah di nilai telah melakukan efisiensi anggaran jika rasio efisiensinya kurang dari $100 \%$, Sebaliknya jika melebihi $100 \%$ maka mengidentifikasikan terjadinya pemborosan anggaran ( Abdul Halim : 2004). Efisiensi Pajak Daerah pada Pemerintah Provinsi Sumatera Utara cukup efisien dalam merealisasikan pajak daerah yang direncanakan dengan rata-rata rasio efisiensi pajak daerah berada diatas 5\%. Hal ini disebabkan oleh bea balik nama kendaraan diatas air,dan pajak air permukaan.

Dilihat dari anggaran dan realisasi belanja kinerja pemerintah Provinsi Sumatera Utara dapat dikatakan cukup baik dalam merealisasikan belanja langsung dan belanja tidak langsung. Pada Belanja Rutin kinerja pemerintah propinsi Sumatera Utara juga dinyatakan cukup baik. Hal ini disebabkan oleh belanja pegawai yang tinggi diatas $85 \%$. Belanja barang dan jasa yang mencapai $90 \%$. Selain itu Belanja Pembangunan yang mengalami peningkatan dimana belanja peralatan dan mesin, belanja tanah dan belanja asset tetap lainnya Hal ini menunjukkan kinerja Pemerintah Provinsi Sumatera Utara cukup baik.

Pada Belanja Langsung dan Belanja Tidak langsung kinerja pemerintah propinsi Sumatera Utara masih kurang efisien, hal ini dikarenakan masih tingginya belanja operasi dan belanja modal. Penyebabnya rasio belanja langsung relatif besar dibandingkan dengan rasio belanja tidak langsung. artinya dari total belanja lebih besar dialokasikan untuk belanja yang terkait dengan program dan kegiatan yang dilakukan pemerintah. 


\section{Published December 2018}

\section{EKONOMIKAWAN : Jurnal Ilmu Ekonomi dan Studi Pembangunan}

ISSN : 1693-7600 (Print), ISSN : 2598-0157 (Online), http://jurnal.umsu.ac.id/index.php/ekawan

Ekonomis adalah perolehan masukan dengan kualitas dan kuantitas tertentu pada tingkat harga yang terendah. Transparan adalah prinsip keterbukaan yang memungkinkan masyarakat untuk mengetahui dan mendapatkan akses informasi seluas-luasnya tentang keuangan daerah. Bertanggung jawab adalah perwujudan kewajiban seseorang untuk mempertanggungjawabkan pengelolaan dan pengendalian sumber daya dan pelaksanaan kebijakan yang dipercayakan kepadanya dalam rangka pencapaian tujuan yang telah ditetapkan. Keadilan adalah keseimbangan distribusi kewenangan dan pendanaannya dan/atau keseimbangan distribusi hak dan kewajiban berdasarkan pertimbangan yang obyektif. Kepatutan adalah tindakan atau suatu sikap yang dilakukan dengan wajar dan proporsional. Manfaat untuk masyarakat adalah bahwa keuangan daerah diutamakan untuk pemenuhan kebutuhan masyarakat.

Kondisi diatas menunjukkan bahwa pengelolaan keuangan pada pemerintah daerah propinsi Sumatera Utara belum berjalan efektif. Hal ini terlihat dari dua hal yaitu dari sisi pendapatan dan sisi pengeluaran. Dari sisi pendapatan ternyata pemerintah Sumataera Utara belum mampu menggali seluruh potensi yang ada untuk mencapai anggaran pendapatan. Sedangkan dari sisi pengeluaran pemerintah daerah sumatera utara juga masih belum dapat mendahulukan pengeluaran yang sifatnya untuk kepentingan masyarakat banyak, hal ini terlihat pada pengeluaran yang terjadi dimana jumlah belanja pegawai, belanja asset serta belanja barang dan jasa masih terlalu tinggi dibanding belanja pembangunan. Dari kenyataan ini terlihat bahwa besarnya realisasi pendapatan belum dapat mengimbangi realisasi pengeluaran sehingga terjadi adanya ketidak seimbangan antara pendapatan dengan pengeluaran.

Perencanaan biasanya ditunjukan dengan adanya penyusunan Anggaran Pendapatan dan Belanja Daerah (APBD) disetiap pemerintah daerah termasuk pemerintah daerah Sumatera Utara. Penyusunan anggarannya dimulai dari menentukan sumber sumber pendapatan daerah. Perencanaan APBD yang diterapkan selama ini terlihat belum mengutama kepentingan masyarakat. Dari sisi penerimaan APBD yang ada saat ini masih lebih mengutamakan penerimaan yang bersumber dari pajak. Sedangkan sumber pendapatan yang berasal dari harta milik Negara dan umum yang tersirat pada Dana Alokasi Umum (DAU) dan Dana Alokasi Khusus (DAK) masih menjadi alternative pilihan pendapatan berikutnya. Sumber dana dari zakat belum digunakan sebagai alternative penerimaan daerah padahal saat ini di daerah ada Badan Amil Zakat Nasional (BAZNAS) yang mengelola dana zakat, infaq dan shadaqah dari masyarakat Indonesia. Dilihat dari alokasi pengeluaran perencanaan APBD yang ada saat ini dalam pengeluarannya diutama untuk kepentingan wajib dahulu kemudian untuk kepentingan skunder dan tertier. Walaupun dalam realisasinya selalu lebih besar pengeluaran untuk kebutuhan skunder dan tertier tersebut.

Setelah perencanaan maka pengelolaan keuangan selanjutnya diarahkan kepada pelaksanaan dan pengawasannya. Dalam pelaksanaannya setiap orang yang diberi tugas dalam pemerintahan tersebut harus bertanggungjawab penuh atas pelaksanaan anggaran ini, dan dapat menjalankannya sesuai dengan atauran atau undang- undang yang berlaku. Hal ini harus dilakukan karena dampak dari pengelolaan keuangan ini adalah kelangsungan hidup orang banyak atau masyarakat. 


\section{Published December 2018}

EKONOMIKAWAN : Jurnal Ilmu Ekonomi dan Studi Pembangunan

ISSN : 1693-7600 (Print), ISSN : 2598-0157 (Online), http://jurnal.umsu.ac.id/index.php/ekawan

Demikian pula dengan pengawasan, pengawasan pengelolaan keuangan daerah sebenarnya merupakan tanggungjawab bersama. Dimana masyarakatlah sebenarnya yang melakukan pengawasan atas pengelolaan keuangan daerah yang ada berdasarkan ketentuan dan aturan yang sudah ditetapkan. Dalam aturan di Indonesia pengelolan keuangan daerah diawasi oleh wakil rakyat yaitu dewan perwakilan rakyat daerah (DPRD). Pada prinsipnya dengan adanya APBD yang terencana dengan baik maka pelaksanaan dan pengawasan juga akan ikut menjadi baik.

Dari hasil observasi diketahui juga bahwa Perencanaan APBD Pengelolaan Keuangan Daerah berdasarkan Permendagri nomor 13 Tahun 2006 terdiri dari 3 bagian yang terdiri dari pendapatan daerah, belanja daerah dan pembiayaan daerah ternyata pembiayaan daerah yang merupakan sumber-sumber penerimaan dan pengeluaran daerah yang dimasudkan untuk menutupi defisit anggaran/sebagai alokasi surplus anggaran belum terlihat jelas pada struktur APBD yang ada padahal dengan adanya pos pembiayaan sebagai upaya menyusun APBD agar menjadi lebih inovatif.

\section{SIMPULAN}

Hasil yang diperoleh dari penelitian dapat disimpulkan sebagai berikut: 1) Pengelolaan Keuangan Daerah Propinsi Sumatera Utara belum efektif dan efisien terlihat dari APBD yang menunjukan realisasi pendapatan dan belanja belum dapat mencapai target. 2) Pada Struktur APBD saat ini masih belum sesuai dengan Permendagri nomor 13 Tahun 2006 pada bagian pembiayaan daerah yang ternyata belum jelas diungkap pada struktur APBD. Selain itu dapat dinyatakan pula bahwa masih perlunya adanya dukungan dari pihak pemerintah daerah Sumatera Utara untuk menganalisis lebih lanjut terhadap struktur APBD dalam meningkatkan Pengelolaan Keuangan Daerah.

\section{DAFTAR PUSTAKA}

Abdul, Halim. 2008. Akuntansi Keuangan Daerah. Cetakan Ketiga. Salemba Empat. Jakarta.

Abu Hasan Ali Al-Mawardi. Al-Ahkam al-Sulthaniyah wa-Wilayat al-Diniayah. Beirut: Dar Al-Fikr, 1996.

Addina, Marizka. 2010. Analisis Kinerja Pengelolaan Anggaran Pendapatan dan Belanja Daerah Pemerintah Kota (Skripsi S1). Universitas Sumatera Utara Indra, Bastian. 2006. Akuntansi Sektor Publik: Suatu Pengantar. Erlangga, Jakarta.

Arsip e-Syariah.Net.Sistem Ekonomi Syariah. 2004. Pengelolaan Keuangan Negara Dalam Islam : Kritik Atas APBN.

Dedi, Nordiawan. 2006. Akutansi Sektor Publik. Andi. Yogyakarta.

Dinas Pendapatan Daerah. 2006. Kebijakan Pengawasan Daerah, Anggaran 2006. Inspektorat Provinsi Sumatra Utara. Medan.

Fatihah. 2014. Analisis Efektivitas Anggaran Pendapatan pada Badan Pengelolaan Keuangan dan Aset Daerah Kabupaten Batu Bara. Skripsi. UMSU

Hidayatullah Muttaqin, 2004. Pengelolaan Keuangan Negara dalam Islam.

Pohan, Kiki Rizkiana, 2015. Analisis Kinerja Anggaran Pendapatan Dan Belanja Daerah Pada Pemerintah Provinsi Sumatera Utara. Skripsi. UMSU.

Mahmudi, 2007. Manajemen Kinerja Sektor Publik. UUP STIM YKPN, Yogyakarta. Mardiasmo, 2002. Otonomi dan Manajemen Keuangan Daerah. Andi, Yogyakarta. 


\section{Published December 2018}

\section{EKONOMIKAWAN : Jurnal Ilmu Ekonomi dan Studi Pembangunan}

ISSN : 1693-7600 (Print), ISSN : 2598-0157 (Online), http://jurnal.umsu.ac.Id/index.php/ekawan

, 2009. Akuntansi SektorPublik. Edisi Keempat. Andi. Yogyakarta.

Republik Indonesia, Kepmendagri Nomor 29 Tahun 2002 tentang Pedoman Pengurusan, Pertangungjawaban dan Pengawasan Keuangan Serta Tata Cara Penyusunan Anggaran Pendapatan dan Belanja Daerah, Pelaksananan Tata Usaha Keuangan Daerah dan Penyusunan Perhitungan Anggaran Pendapatan dan Belanja Daerah. Undang-undang Nomor 17 tahun 2003 tentang Keuangan Negara. , Undang-undang Nomor 32 tahun 2004 tentang Pemerintah Daerah. Undang-Undang Nomor 33 tahun 2004 tentang Perimbangan

Keuangan antara Pemerintah Pusat Peraturan Daerah. , Peraturan Menteri Dalam Negeri Nomor 13 tahun 2006 tentang Pedoman Penyusunan APBD tahun Anggaran 2007. , Peraturan Pemerintah Nomor 58 tahun 2005 tentang Pengelolaan Keuangan Daerah.

Sinambela, Elizar dan Saragih, Fitriani. 2013. Pengembangan Model Pengawasan Keuangan Daerah dalam Meningkatkan Kinerja Dewan. Laporan Hasil Penelitian.

Yuwono, S, I.T. Agus, dan Hariyadi. 2005. Penganggaran Sektor Publik, Pedoman Praktis, Penyusunan, Pelaksanaan dan Pertanggungjawaban APBD (Berbasis Kinerja). Bayumedia Publising, Malang http://famhar.multiply.com/journal/item/179. http://bimtek pelatihan.blogspot.com/2015/06 